\title{
Relationship between Brand Equity and Corporate Governance Disclosures: A Study of Top 20 Brands in India
}

\section{Pankaj Mishra*}

Department of Economics, Aligarh Muslim University, Aligarh, Uttar Pradesh, India

\begin{abstract}
This study examines the relationship between brand equity and corporate governance of firms by using disclosures as the measure of corporate governance. Top 20 Indian brands have been tested using correlation and regression to examine the association and relationship between their brand equity and their corporate governance disclosure score. The study revealed significant correlation between overall corporate governance disclosure and brand equity for the year 2016. Strength of Board Committees was the only corporate governance component that showed significant correlation with brand equity. Regression revealed significant relationship between overall corporate governance disclosure score and brand equity with 33 per cent variation in brand equity explained by overall corporate governance disclosure Score for 2016. Investor Relations explained for 40 per cent variation in Brand Equity in 2016. Not all aspect of corporate governance however impacts brand equity. Strong brand management with effective corporate governance can be one of the means to achieve enhanced Brand Equity.
\end{abstract}

Keywords: Brand equity; Corporate governance; Brand value; Board of directors; Shareholder

\section{Introduction}

Corporate Governance is concerned with management of relationship between the directors, managers and other stakeholders of an organisation. It specifically strives to achieve the set values, and vision and create visibility of the organisational functioning [1]. It is the system by which companies are directed and controlled [2]. The concept gained focus as a response to corporate failures and dissatisfaction with the way the organisations are managed [3]. The interplay of stakeholders with organisation has attracted lot of studies and instances of corporate noncompliances and misjudgements kept igniting the debate on corporate governance [4].

While organisations have started to appreciate the significance of corporate governance, still it is administered or enforced through legislations, regulations and disclosures. Enforcement through government, private (e.g. civil suits filed by shareholders), and liability to suppliers have been witnessed across countries [5]. In the case of India, mandatory certification to Securities and Exchange Board of India (SEBI) by companies listed in the stock exchanges and enforcement through companies act 2013, are some of the means to ascertain and enforcement corporate governance compliances.

There have been numerous studies centered around linkage of corporate governance and a firm's performance. Some of the measures of a firm's performance are competitiveness, market share, growth and brand value. Tobin's Q, Return in Equity (ROE), Return on Asset (ROA) are some of the common measures that have been used to ascertain a firm's performance vis-à-vis corporate governance. Effective corporate governance is often linked to firm's performance, sustainability, access to capital, reduced vulnerability to financial crises and reduced transaction costs $[6,7]$.

A firm's Brand Equity is one of the key parameter relating to its performance. Brand Equity is the added value endowed by the brand to the product [8]. Brand Equity represents the total value of a brand as a separable asset, a measure of the strength of consumer's attachment to a brand and a description of the associations and beliefs of the consumer about the brand [9]. Companies with a positive brand image have higher market value, own a market value premium and generate an intangible asset vis-à-vis industry peers [10]. In 2004, a Financial times survey (across 903 chief executives in 20 countries) on most respected companies maintained a high score on financial performance, integrity, commitment to the community and corporate governance [11]. Hence studying how corporate governance disclosures impact this measure of firm's performance is very important. It will help firms to evaluate if their corporate governance actions are building value and if they are getting associated with their customers. For shareholders, this will provide another measure of firm's performance assessment, thereby reducing the information asymmetry and agency cost.

While there are studies on ascertaining relationship between corporate governance and firm's performance through parameters like Tobin's Q, ROE and ROA, there are fewer studies to ascertain linkage between Brand Equity and corporate governance. This study adds to the current literature in terms of evaluating this dimension of firm's performance specially in the context of India. This study focuses on top 20 Brands of India and shall ascertain if there is a linkage between their Brand Equity and the corporate disclosures they make. The specific research objective is to determine if corporate governance disclosures impact brand equity of Indian firms. The study relies on a combination of Corporate Governance Index suggested by Black et al., [12] and Subramaniana and Reddy [13]. Brand Equity figures published by Interbrand for Indian Brands. The mandatory disclosures required under the Companies Act 2013 and under SEBI's listing obligations which shall be the foundation of ascertaining corporate governance. Correlation and regression is used as the primary statistical tool.

*Corresponding author: Mishra $\mathrm{P}$, Department of Economics, Aligarh Muslim University, Aligarh, Uttar Pradesh, India, Tel: +919810791847; E-mail: mishra2016pankaj@gmail.com

Received May 07, 2017; Accepted May 18, 2018; Published May 25, 2018

Citation: Mishra P (2018) Relationship between Brand Equity and Corporate Governance Disclosures: A Study of Top 20 Brands in India. Bus Eco J 9: 355. doi: 10.4172/2151-6219.1000355

Copyright: (c) 2018 Mishra P. This is an open-access article distributed under the terms of the Creative Commons Attribution License, which permits unrestricted use, distribution, and reproduction in any medium, provided the original author and source are credited. 


\section{Literature Review}

Notwithstanding the numerous studies done to ascertain the impact of corporate governance on firm's performance, there continues to be a contrary view in terms of the outcome. Black et al. [12], suggest that better corporate governance does not predict higher firm profitability but appears to predict lower cost of external capital. Goel and Ramesh [14,15] on the other hand found a positive impact of corporate governance practices on valuation and profitability. Arora and Sharma [16], found the relationship between corporate governance and performance not very strong in Indian firms. They found no relationship between ROE, profitability and stock returns, with corporate governance indicators of the firms. Brown and Caylor [17] evidenced no relation between corporate governance measures and firm's valuation.

Subramaniana and Nagi [13] in their study of Indian firm's international competitiveness found that corporate governance disclosures may improve market share. Ioannou and Serafeim [18] suggest that sustainability reporting not only increases transparency but can also change corporate behavior and there is a positive impact of this on responsible management practices. Bauer et al. [19] on the other hand found quantified impact of corporate governance on firm's performance in Japan. Well-governed firms were found to be significantly outperforming the poorly governed firms by up to 15 per cent a year. Financial disclosure, internal control, shareholder rights, and remuneration significantly impacted stock performance. They were however cautious to point out that not all aspects of corporate governance matter to shareholders [19]. Positive correlation has been found between good governance with market valuation and operating performance [20].

Ettredge et al. [21], in their study noted that features of the board of directors, the audit committee, and the strength of internal controls were significantly associated with disclosure compliance. Reflecting good governance through disclosure compliance was seen to be driven by active board and board committees. They further evidenced that board and ownership structure were more reliable about predicting future accounting operating performance than future stock market performance. Core et al. [22] found firms with weaker governance structures having greater agency problems and perform worse. They however cautioned that corporate governance and performance might be endogenous.

The corporate governance parameters considered in this study have been evidenced to impact firm's performance in the Indian context as well. Bhatt and Bhattacharya [23] and Erkens et al. [24] found that firms with higher institutional ownership and more independent boards had worse stock returns than other firms during the crisis. Kumar and Singh [25] found negative association between board size and firm value and firms with high ownership concentration of promoters have high market valuations. Executive chairperson has been found to affects the firm value and optimal combination of inside and outside directors, (independent directors) key to driving firm performance [26]. Directors pay impacts the profit after tax across various industries and firms of varied sizes. It has also been found that firms with weaker corporate governance have lower credit ratings [27].

With respect to evaluating Brand Equity as a measure of firm's performance, various studies have been done including for studies on specific dimensions which relate to Brand Equity and overall firm's performance. Dowling [28] reported from his study, that good reputation aids the company and results in better financial performance in general. Studies have also revealed that Brand value is directly related to shareholder's value [29] and is a preferred performance measure as it creates a long-term focus for management [9]. Firms with strong brands, create value for their shareholders through greater returns with less risk [30]. Brand equity increases both consumer preferences and purchase intentions [31].

Corporate governance is one of the strong means to enhance reputation and hence improving performance of the brand. Brand value is influenced by corporate identity which is transmitted by corporate communications, corporate design and corporate behaviour [32]. Disclosures being are a form of corporate communication is likely to hence play a role in brand equity outcomes. Social responsibility is key to successful brands and growing brand value, as consumers want to feel responsible in what they consume [33]. Singh and Kumar [34] further submit that effective internal monitoring can improve the performance of the firms and higher disclosure standards have positive impact on performance. By Improving board practices and voluntary disclosures of the same can improve a firm's market share and relative growth rate in the international market [13].

Improved corporate governance structure requires the firms to be operated differently and reflect changes in managers' behaviour [35] With better Corporate Governance, firms can achieve greater returns on their capital invested [36]. This is further supported by Lai et al. [37] who in their study conclude that, for improving financial performance of brands, managers must enhance their corporate reputation and prevent it from falling.

One of the key parameters of shareholder value namely Earnings per Share (EPS) has also been found to be impacted by the directors pay [38]. Mandatory corporate governance disclosures have been found to bring in efficient supervision of managers by boards of directors and increased implementation of ethical practices [18], which in turn impacts the brand value of a firm. Ploscaru et al. [39] through their research suggested to integrate corporate governance into brand management in view of the value corporate governance showed in their studies.

If a company's corporate governance is sound and focused on long term, it will lead to growing trust and reputation. Many companies see branding as an output of their corporate governance activities. British Petroleum (BP) has used corporate governance to differentiate from rivals. Diageo has relied on corporate governance to build distinct brand values [40]. Corporate governance is positively associated with Corporate Social Responsibility (CSR) and expected to have an impact on future social responsibility of the firm thereby enhancing reputation [41].

Effective corporate governance leads to lower costs and more equitable capital and it influences market orientation. It is key factor in decision of releasing new product information due to its influence on market orientation behaviors of the firm. An effective corporate control system along with market-oriented strategies can stimulate customers' needs [42]. In Korea's digital cellular phone market Srinivasan et al. [43] found brand awareness contributing the most to brand equity the largest. They also evidenced substantial impact of a brand's equity on brand's market share. Bhojraj and Sengupta [44] in their study of effect of corporate governance and bond value, concluded that effective corporate governance affect's bond yields and ratings through its impact on default risk of the firm. In their study, they also noted that governance mechanisms reduce expropriation or misallocation of funds, and lead to a long-term planning horizon. This in turn impacts 
the perception of the bondholders, resulting in a reduction in the firms' default risk. This finding can be extrapolated to mean that the improved perception would impact the reputation and the Brand value.

Sustainability, corporate governance and innovation are important drivers of brand strength in B2B markets. Particularly in the case of India, Brand strength perception showed strong association with sustainability and corporate governance [45]. In a study of Turkish firms, Aktaş et al. [46] found shareholders, public disclosure and transparency ratings having significant and positive effects on brand value. Corporate governance behavior has considerable impact on market value in a country where legal and cultural constraints on corporate behavior are weak [14].

There are varied and rich literature on analysis of relationship between corporate governance and firm's performance. These are however, focused on evaluating relationship of popular measures like Tobin's Q, ROA, ROE, profitability and so on with corporate governance. Fewer studies analysed the relation between corporate governance and Brand Equity. Moreover, these studies have been provided varied arguments. For instance, Ünlü and Yagli [47], found no significant relationship, while Tuan [48], found significant impact of Corporate governance on brand performance. Tuan [48] even recommended inclusion of corporate governance scorecards into the performance management system of the firms. Lennartz et al. [45] in their study found corporate governance as one of the elements driving brand strength in B2B markets across all countries and industries. Aktaş et al. [46] in their study of Corporate Governance and Brand value of Turkish firms, found significant and positive effects of shareholders, public disclosure and transparency ratings on brand value.

Notwithstanding the importance of these studies, an India specific study is required as corporate governance practices vary between countries. Craig et al. [49] found firms in countries with low financial and economic development preferring less investment in governance. They studied CLSA corporate governance ratings, the Standard \& Poor's (S\&P) transparency and disclosure ratings, and the FTSE ISS governance scores and found large variation attributable to country characteristics. Even for a common market like Bauer et al. [50] found substantial differences between the U.K. market and the Eurozone markets. These are interesting finding and an encouragement for an India specific study as review of current literature suggest limited India specific studies.

This study is motivated by this situation and is aimed at finding a relationship between corporate governance disclosures and the Brand Equity of Top 20 Brands in India. The study leverages on the various corporate governance disclosures done by firms to meet requirements by SEBI, and Companies act 2013. The Brand Equity values published by Interbrand have been used as the base.

Earlier studies by on various aspects of corporate governance disclosures made by Indian firms have been used to arrive at the required framework. Madhani [51-54] evidenced no significant difference in the corporate governance disclosure of public and private firms in India. This helped in considering both kind of companies without bias. Since the disclosures have insignificant correlation to the industry type [52], there was no constraints in choosing firms from heterogenous industry as outcome was not expected to get impacted.

\section{Hypothesis}

Based on the literature review and in line with the objective of the study the following hypothesis were framed and further tested.
$\mathrm{H}_{0 \mathrm{a}}$ : There is no significant correlation between Brand Equity of top 20 brands of India and Corporate Governance Disclosures of these brands in 2016.

$\mathrm{H}_{0 \mathrm{~b}}$ : There is no relationship between Brand Equity of top 20 brands of India and Corporate Governance Disclosures of these brands in 2016 .

$\mathrm{H}_{0 \mathrm{c}}$ : There is no relationship between Brand Equity of top 20 brands of India and lagged Corporate Governance Disclosures of these brands from year 2015 .

$\mathrm{H}_{\text {od: }}$ : There is no relationship between Brand Equity of top 20 brands of India and functioning of board committees and Investor relations of these brands.

There are various aspects of corporate governance that can be identified from the disclosures made by the companies in India, in their Annual Report. The ownership structure of a firm, its board structure and Independence, the rigor of its board, strength of the board committees, remuneration policies and investor relations are very important corporate governance parameters that are available from these disclosures. These parameters were considered as independent variables and were tested for their impact on Brand Equity as the dependent outcome.

\section{Methodology}

The study was done using secondary data available in the public domain. The Brand Equity figures of Top Brands of India and the Corporate Governance Disclosures of these firms were the two sets data used in the study. Brand Equity data was taken from the Interbrand publications of Top 40 Indian Brands and Corporate governance Disclosures data was collected from the Annual Reports of the firms.

\section{Sampling plan}

Top 20 Indian brands were drawn from a list of Top 40 Brands published by Interbrand for the year 2016 and 2015. This sampling was done after thorough evaluation of the Brand performance data published by BrandZ, TRA Research, Brand Finance and Forbes. These publications use different Brand Equity valuation criteria, with some criteria overlaps between them. These were used in unison to minimise rating bias of a specific publication (Interbrand).

Interbrand is widely followed in marketing community and draws credibility as it was the first one to meet the ISO 10668 requirement in 2010. One of its valuation criteria is 'transparent in financial results', which is closely associated with corporate governance $[55,56]$.

The study excluded Life Insurance Corporation of Indian (LIC) and banks that featured in Top 20 Brands, as they are governed by different regulation when compared to rest of the companies $[13,36]$. Tata Consultancy Services (TCS) was chosen to represent the Tata Group and Titan represented (being the owner) the brand Tanishq.

\section{Data collection}

Brand Equity values were taken from Interbrand publication for year 2015 and 2016. A questionnaire on Corporate Governance Disclosures used by Subramaniana and Reddy [13] and Sharma and Khanna [57] was used to collect the disclosure data. The questionnaire had 67 questions across six categories/sub-indices covering Ownership, Board Structure, Board meetings, Board committees, Remuneration and Investor Relations. Response to these questions on Corporate Governance Disclosures was collected from the annual reports of 
Citation: Mishra P (2018) Relationship between Brand Equity and Corporate Governance Disclosures: A Study of Top 20 Brands in India. Bus Eco J 9: 355. doi: 10.4172/2151-6219.1000355

Page 4 of 9

the selected firms. The questionnaire is reproduced in Tables 1-4 of Annexure 1.

A binary scoring was done, where if the answer to a corporate governance disclosure question was available in the Annual Report a score of ' 1 ' was assigned and a score of ' 0 ' otherwise was assigned $[12,13,36,57]$. The score across all the 67 questions with equal weight was summed up to arrive at Overall Corporate Governance Disclosure Score of the firm. Score of each the six categories were similarly arrived at by combining the scores of questions in that category [12].

\section{Variables and statistical tool used}

Brand Equity (BE) was the dependent variable. Overall Corporate Governance Disclosure Score (CGDS) and the Corporate Governance

\begin{tabular}{|l|l|}
\hline Dependent Variable & \\
\hline BE & Reciprocal of Brand Equity value of each of the Firms selected as Top 20 brands \\
\hline Independent Variable & \\
\hline & Corresponding Corporate Governance Measure \\
\hline OS & Ownership Structure. \\
\hline BSI & Board Structure and Independence. \\
\hline BMR & Board Meeting Rigor. \\
\hline SBC & Strength of Board Committees. \\
\hline RPD & Remuneration Policy and Disclosure. \\
\hline IR & Investor Relations. \\
\hline CGDS & Overall Corporate Governance Disclosure Score \\
\hline
\end{tabular}

Table 1: Variables used in the study.

\begin{tabular}{|c|c|c|c|c|}
\hline \multirow[b]{2}{*}{ Statistics } & \multicolumn{2}{|c|}{ CGDS-Corporate Governance Disclosure } & \multicolumn{2}{|c|}{ Brand Equity } \\
\hline & 2016 & 2015 & 2016 & 2015 \\
\hline Mean & 53.45 & 52.2 & 155.32 & 144.05 \\
\hline Standard Error & 0.75 & 0.94 & 37.01 & 33.61 \\
\hline Median & 52.5 & 52 & 101.24 & 90.65 \\
\hline Mode & 52 & 47 & \#N/A & $\# N / A$ \\
\hline Standard Deviation & 3.36 & 4.21 & 165.53 & 150.29 \\
\hline Sample Variance & 11.31 & 17.75 & 27399.32 & 22587.87 \\
\hline Kutosis & -0.85 & -0.65 & 8.24 & 7.69 \\
\hline Skewness & 0.49 & 0.56 & 2.68 & 2.61 \\
\hline Range & 11 & 13 & 700.79 & 629.81 \\
\hline Minimum & 48 & 47 & 41.39 & 39.59 \\
\hline Maximum & 59 & 60 & 742.18 & 669.4 \\
\hline Sum & 1069 & 1044 & 3106.35 & 2880.92 \\
\hline Count & 20 & 20 & 20 & 20 \\
\hline Confidence Level (95.0\%) & 1.57 & 1.97 & 77.47 & 70.34 \\
\hline
\end{tabular}

Table 2: Descriptive Statistics of Brand Equity and Corporate Governance Disclosure Score.

\begin{tabular}{|c|c|c|c|c|c|c|c|c|c|c|c|c|}
\hline \multirow[t]{2}{*}{ Statistics } & \multicolumn{2}{|c|}{$\begin{array}{l}\text { BSI-Board Structure } \\
\text { and Independence }\end{array}$} & \multicolumn{2}{|c|}{$\begin{array}{l}\text { BMR-Board Meeting } \\
\text { Rigor }\end{array}$} & \multicolumn{2}{|c|}{$\begin{array}{c}\text { SBC-Strength of Board } \\
\text { committes }\end{array}$} & \multicolumn{2}{|c|}{$\begin{array}{l}\text { RPD-Remuneration } \\
\text { Policy of Disclosure }\end{array}$} & \multicolumn{2}{|c|}{$\begin{array}{l}\text { OS-Ownership } \\
\text { Structure }\end{array}$} & \multicolumn{2}{|c|}{ IR-Investor Relations } \\
\hline & 2016 & 2015 & 2016 & 2015 & 2016 & 2015 & 2016 & 2015 & 2016 & 2015 & 2016 & 2015 \\
\hline Mean & 10.1 & 9.6 & 5.45 & 4.85 & 14.15 & 13.5 & 7.05 & 7.3 & 10 & 10 & 6.7 & 6.95 \\
\hline Standard Error & 0.38 & 0.35 & 0.27 & 0.25 & 0.33 & 0.4 & 0.17 & 0.13 & 0 & 0 & 0.19 & 0.2 \\
\hline Median & 10 & 9 & 5 & 4.5 & 14 & 14 & 7 & 7 & 10 & 10 & 7 & 7 \\
\hline Mode & 9 & 8 & 5 & 4 & 14 & 14 & 7 & 7 & 10 & 10 & 7 & 7 \\
\hline $\begin{array}{l}\text { Standard } \\
\text { Deviation }\end{array}$ & 1.68 & 1.57 & 1.19 & 1.14 & 1.46 & 1.79 & 0.76 & 0.57 & 0 & 0 & 0.86 & 0.89 \\
\hline $\begin{array}{l}\text { Sample } \\
\text { Variance }\end{array}$ & 2.83 & 2.46 & 1.42 & 1.29 & 2.13 & 3.21 & 0.58 & 0.33 & 0 & 0 & 0.75 & 0.79 \\
\hline Kurtosis & -1.13 & -1.31 & -0.58 & -0.68 & 1.81 & 0.65 & 1.72 & -0.4 & - & - & 0.52 & 0.73 \\
\hline Skewness & 0.34 & 0.48 & 0.44 & 0.56 & 1.06 & 0.37 & -0.89 & -0.04 & - & - & -0.97 & -0.9 \\
\hline Range & 5 & 4 & 4 & 4 & 6 & 7 & 3 & 2 & 0 & 0 & 3 & 3 \\
\hline Minimum & 8 & 8 & 4 & 3 & 12 & 11 & 5 & 6 & 10 & 10 & 5 & 5 \\
\hline Maximum & 13 & 12 & 8 & 7 & 18 & 18 & 8 & 8 & 10 & 10 & 8 & 8 \\
\hline Sum & 202 & 192 & 109 & 97 & 283 & 270 & 141 & 146 & 200 & 200 & 134 & 139 \\
\hline Count & 20 & 20 & 20 & 20 & 20 & 20 & 20 & 20 & 20 & 20 & 20 & 20 \\
\hline $\begin{array}{l}\text { Confidence } \\
\text { Level }(95.0 \%)\end{array}$ & 0.79 & 0.73 & 0.56 & 0.53 & 0.68 & 0.84 & 0.36 & 0.27 & 0 & 0 & 0.4 & 0.42 \\
\hline
\end{tabular}

Table 3: Descriptive Statistics of Corporate Governance Sub-Indices. 
score across the six category/sub-indices were the independent variables. The Table 1 below list the variables used in the study.

The above variables were tested as per the below steps, to evidence if Corporate Governance impacts the Brand equity of Top 20 Brands in India.

Step1: A correlation between the dependent variable and independent variable was carried out using Spearman Correlation, to test dependence or association.

Step2: To test the relationship between corporate governance disclosures and brand equity, the following simultaneous equations were used.

$$
\begin{gathered}
B E_{\text {Yearl }}=f 1\left(C G D S_{\text {yearr }}, \epsilon_{1}\right) \\
B E_{\text {Year } 2}=f 2\left(C G D S_{\substack{\text { year2, } \\
(1 a)}}, \epsilon_{2}\right)
\end{gathered}
$$$$
B E_{\text {Year } 2}-B E_{\text {Yearl }}=f 3\left(\left(C G D S_{\text {year } 2}-C G D S_{\text {year } 1}\right), \epsilon_{3}\right)
$$$$
\text { (1c) }
$$$$
B E_{\text {Yearl } 1}=f_{4}\left(O S_{\text {year } 1}, B S I_{\text {year } 1}, B M R_{\text {year } 1} S B C_{\text {yearl } 1} R P D_{\text {yearl } 1} I R_{\text {year } 1}, \epsilon_{4}\right)
$$$$
\text { (1d) }
$$$$
B E_{\text {Year } 2}=f_{5}\left(O S_{\text {year } 2}, B S I_{\text {year } 2}, B M R_{\text {year } 2}, S B C_{\text {year } 2}, R P D_{\text {year } 2}, I R_{\text {year } 2}, \in_{5}\right)
$$$$
\text { (1e) }
$$$$
B E_{\text {Year } 2}=f_{6}\left(O S_{\text {year } 1}, B S I_{\text {year } 1}, B M R_{\text {year } 1} S B C_{\text {year } 1}, R P D_{\text {year } 1} I R_{\text {year } 1}, \epsilon_{\sigma}\right)
$$$$
(1 f)
$$

$B E_{\text {Year } 2}-B E_{\text {Year } 1}=\left[f_{7}\left(\left(O S_{\text {year } 2}-O S_{\text {year } 1}\right),\left(B S I_{\text {year } 2}-B S I_{\text {year } 1}\right),\left(B M R_{\text {year } 2}-\right.\right.\right.$
$\left.B M R_{\text {year } 1}\right),\left(S B C_{\text {year } 2}-S B C_{\text {year } 1}\right),\left(R P D_{\text {year } 2}-R P D_{\text {year } 1}\right),\left(I R_{\text {year } 2}-I R_{\text {year } 1}\right), \epsilon_{7}$

Where $\epsilon_{i}$, is the error associated with the variables which were not observed and/or was not considered. Year 1 means year 2015 and year2 represents year 2016 .

Linear regression was carried out to test the data which is substantiated by the fact that earlier studies have found linear relationship between corporate governance practices with firm competitiveness [13]. Further robustness test was also carried out to test this premise of linearity using Passing and Bablok regression.

\section{Results and Discussion}

The collected data on Brand Equity and Corporate Governance Disclosures were subjected to the test mentioned under the section on methodology. Following are the key results of the various statistical test.

\section{Descriptive statistics}

Outcome of the statistical analysis of the Brand Equity data and
Corporate Governance Disclosure data is provided in Table 2 below. The mean Brand Equity and Corporate Governance Disclosure score of the Top 20 brands increased year on year. The median value of Brand Equity and Corporate Governance Disclosure score also improved from year 2015 to year 2016. Standard deviation of the Corporate Governance Disclosure scores reduced from 4.21 to 3.36, while the standard deviation of Brand Equity increased. This indicated widening of gap in the Brand Equity values year on year between these top 20 brands. Similar statistics were noted in the form of sample variance which declined in the case of Corporate Governance Disclosure score, but increased in the case of Brand Equity values.

Skewness score of Brand Equity and Corporate Governance Disclosure score are positive, suggesting that both these data are skewed to the right. The skewness value of Corporate Governance Disclosure indicated a normal distribution.

The descriptive statistics of the sub-indices were also carried out (detailed in Table 3 below) revealing right skewed normal distribution. The ownership structure score was constant between year 2016 and year 2015 and acted as constant during regression and correlation tests.

\section{Correlation results}

The results of the Spearman rank correlation between Brand Equity and Corporate Governance disclosures is provided the Table 4 below. The correlation between Brand Equity values for 2016 and the Overall Corporate Governance Disclosure score for the year 2016 was significant with correlation coefficient of 0.57 at a p-value of 0.009 . This correlation was at a significance level of 95 per cent. This suggested significant correlation between the Brand Equity value and Corporate governance disclosure. The hypothesis $H_{0 a}$ : There is no significant correlation between Brand Equity of top 20 brands of India and Corporate Governance disclosures of these brands in 2016' is hence rejected. This is in line with the finding for Indian firms that companies with better corporate governance mechanisms earning higher market returns [58-60].

The correlation between the Brand Equity figures of 2016 and the corporate governance disclosure sub-indices for the year 201695 per cent significance level gave a different result. Brand Equity showed a significant correlation only with Strength of Board Committees. The correlation coefficient was 0.47 at a $p$ value of 0.03 . Strength of Board Committee relates to the functioning of Audit Committee, Nomination and Remuneration Committee of a firm. A better functioning creates a positive view on financial transactions. Independent audit committees and remuneration policies contain the agency problem. These outcomes are expected to create a sense of association thereby driving Brand value. This is in line with earlier findings where a positive relationship between board meeting and firm performance was noted $[16,61,62$,$] .$

\begin{tabular}{|c|c|c|c|c|c|c|c|c|}
\hline Variables & CGDS 2016 & CGDS 2015 & BSI & BMR & SBC & RPD & os & IR \\
\hline \multirow[t]{2}{*}{ BE 2016} & 0.579 & 0.284 & 0.375 & 0.435 & 0.474 & -0.074 & & 0.128 \\
\hline & $0.009^{*}$ & $0.224^{*}$ & $0.104^{*}$ & $0.057^{*}$ & $0.036^{*}$ & $0.036^{*}$ & NA & $0.589^{*}$ \\
\hline \multirow[t]{2}{*}{ BE 2015} & & 0.289 & 0.344 & 0.402 & 0.174 & 0.174 & & -0.115 \\
\hline & NA & $0.216^{*}$ & $0.138^{*}$ & $0.80^{*}$ & $0.463^{*}$ & $0.463^{*}$ & NA & $0.629^{*}$ \\
\hline \multicolumn{9}{|c|}{2015 Variables } \\
\hline Variables & $\mathrm{BSI}$ & BMR & SBC & RPD & OS & IR & & \\
\hline \multirow[t]{2}{*}{ BE 2016} & 0.325 & 0.377 & 0.19 & 0.263 & & -0.073 & & \\
\hline & $0.162^{*}$ & $0.102^{*}$ & $0.421^{*}$ & $0.261^{*}$ & & $0.759^{*}$ & & \\
\hline
\end{tabular}

Ownership structure was expected to show correlation with Brand

* $p$-values (Spearman): Values in bold are different from 0 with a significance level alpha $=0.05$

Table 4: Correlation test results (Spearman Correlation). 
Citation: Mishra P (2018) Relationship between Brand Equity and Corporate Governance Disclosures: A Study of Top 20 Brands in India. Bus Eco J 9: 355. doi: 10.4172/2151-6219.1000355

Page 6 of 9

Equity as earlier studies [16] suggested institutional shareholding is a key signal to other investors which may lead to demand for such shares and, thus, improve valuation [63]. However, as this index was constant across firms, it did not show any association.

Insignificant correlation of other sub-indices with Brand Equity is an area for further study, as parameter like Investor Relations which is directly connected with the shareholders was expected to show association with Brand Equity. The test however did not align to the general understanding.

\section{Regression results}

Regression was carried between reciprocal of Brand equity value as the dependent variable and the Corporate Governance Disclosure scores as the independent variable(s). To ensure that Linear regression was a suitable measure method validation was carried out using Passing and Bablok regression at 95 per cent confidence level. For the year 2016, Passing and Bablok regression between Brand Equity and Corporate provided a p-value of 0.400 (two tailed) thereby confirming that the relationship was linear (Table 2, in Annexure 1). The result of the regression test at 95 per cent significance level is detailed in the Tables 5 and 6 below.

Testing Hypothesis: $\boldsymbol{H}_{\boldsymbol{o b}}$ : There is no relationship between Brand
Equity of top 20 brands of India and Corporate Governance disclosures of these brands in 2016.

For the year 2016, regression between Brand Equity and corporate governance at 95 percent significance level resulted in $\mathrm{R}^{2}$ of 0.331 and adjusted $R^{2}$ value of 0.294 . The standard error was 0.005 when the regression was carried. The corresponding p-value for the intercept and coefficient of CGDS was 0.002 and 0.008 respectively. Since the $\mathrm{p}$-value is $<0.05$, the null hypothesis is rejected. The $\mathrm{R}^{2}$ value indicated that 33 per cent variation in Brand Equity of 2016 can be explained by Corporate Governance Disclosure Score for that Year. This aligns with earlier evidence provided by Kumar et al [36], Agarwal [59] and Varsney et al. [60] indicating positive relationship between Corporate governance and firm's performance.

The p-value for the F-test of overall significance is 0.007 which is $<0.05$, the significance level of the test. The ANOVA statistics to this effect is shown in Table 7 below. The statistics indicated that the model used provides a better fit than the intercept-only model.

Testing Hypothesis: $\mathbf{H}_{0 \mathrm{c}}$ : There is no relationship between Brand Equity of top 20 brands of India and lagged Corporate Governance disclosures of these brands from year 2015.

When regression of Brand equity for 2016 was carried out with

\begin{tabular}{|c|c|c|c|c|c|c|c|}
\hline \multicolumn{2}{|c|}{ BE 2016} & \multicolumn{2}{|c|}{ BE 2015} & \multicolumn{2}{|c|}{ BE 2016} & \multicolumn{2}{|c|}{$\Delta \mathrm{BE}$} \\
\hline Intercept & 0.0768 & Intercept & 0.0423 & Intercept & 0.0386 & Intercept & 8.068 \\
\hline & $0.002^{*}$ & & $0.055^{\star}$ & & $0.068^{*}$ & & $0.087^{*}$ \\
\hline \multirow[t]{2}{*}{ CGDS 2016} & -0.0012 & CGDS 2015 & -0.0006 & CGDS 2015 & -0.0005 & $\triangle \mathrm{CGDS}$ & 1.563 \\
\hline & $0.008^{*}$ & & $0.159^{*}$ & & $0.189^{*}$ & & $0.214^{*}$ \\
\hline Sample size & 20 & Sample size & 20 & Sample size & 20 & Sample size & 20 \\
\hline SEE & 0.006 & SEE & 0.007 & SEE & 0.007 & $\mathrm{R}^{2}$ & 0.0843 \\
\hline $\mathrm{R}^{2}$ & 0.331 & $\mathrm{R}^{2}$ & 0.107 & $\mathrm{R}^{2}$ & 0.094 & Adjusted $\mathrm{R}^{2}$ & 0.0334 \\
\hline Adjusted $\mathrm{R}^{2}$ & 0.294 & Adjusted $\mathrm{R}^{2}$ & 0.057 & Adjusted $\mathrm{R}^{2}$ & 0.044 & SEE & 16.516 \\
\hline $\mathrm{F}$ & 8.918 & $\mathrm{~F}$ & 2.15 & $\mathrm{~F}$ & 1.864 & $\mathrm{~F}$ & 1.656 \\
\hline
\end{tabular}

Table 5: Linear regression test between brand equity and corporate governance disclosure score for 2016 and 2015.

\begin{tabular}{|c|c|c|c|c|c|c|c|c|c|}
\hline \multicolumn{2}{|c|}{ BE 2016} & \multicolumn{2}{|c|}{ BE 2015} & \multicolumn{2}{|c|}{ BE 2016} & \multicolumn{2}{|c|}{ BE 2016} & \multicolumn{2}{|c|}{$\Delta \mathrm{BE}$} \\
\hline Intercept & 0.067 & Intercept & 0.024 & Intercept & 0.026 & Intercept & 0.01 & Intercept & 5.37 \\
\hline & $0.065^{*}$ & & $0.413^{*}$ & & $0.352^{*}$ & & 0.0537 & & $0.608^{*}$ \\
\hline \multirow[t]{2}{*}{ BSI-2016 } & -0.0004 & BSI-2015 & -0.001 & BSI-2015 & -0.0005 & $\Delta \mathrm{BSI}$ & 0.0007 & $\Delta \mathrm{BSI}$ & -0.271 \\
\hline & $0.678^{*}$ & & $0.526^{*}$ & & $0.721^{*}$ & & $0.5077^{*}$ & & $0.918^{*}$ \\
\hline \multirow[t]{2}{*}{ BMR-2016 } & -0.001 & BMR-2015 & -0.002 & BMR-2015 & -0.0018 & $\Delta \mathrm{BMR}$ & 0.0008 & $\Delta \mathrm{BMR}$ & -0.465 \\
\hline & $0.221^{*}$ & & $0.443^{*}$ & & $0.449^{*}$ & & $0.552^{*}$ & & $0.896^{*}$ \\
\hline \multirow[t]{2}{*}{ SBC-2016 } & -0.002 & SBC-2015 & 0.0001 & SBC-2015 & 0.0002 & $\Delta \mathrm{SBC}$ & -0.001 & $\Delta \mathrm{SBC}$ & 2.707 \\
\hline & $0.158^{*}$ & & $0.929^{*}$ & & $0.8784^{*}$ & & $0.2357^{*}$ & & $0.244^{*}$ \\
\hline \multirow[t]{2}{*}{ RPD-2016 } & -0.00009 & RPD-2015 & 0.0003 & RPD-2015 & -0.0008 & $\triangle \mathrm{RPD}$ & 0.0003 & $\triangle \mathrm{RPD}$ & 1.677 \\
\hline & $0.967^{*}$ & & $0.942^{*}$ & & $0.849^{*}$ & & $0.7609^{*}$ & & $0.447^{*}$ \\
\hline \multirow[t]{2}{*}{ OS-2016 } & $N A^{* * * *}$ & OS-2015 & $N A^{* * * *}$ & OS-2015 & $N A^{* * * *}$ & $\Delta \mathrm{OS}$ & $N A^{* * * *}$ & $\Delta \mathrm{OS}$ & $N A^{* * * *}$ \\
\hline & $N A^{* * * *}$ & & $N A^{* * * *}$ & & $N A^{* * * *}$ & & $N A^{* * * *}$ & & $N A^{* * * *}$ \\
\hline \multirow[t]{2}{*}{ IR-2016 } & -0.002 & IR-2015 & 0.0004 & IR-2015 & 0.000412 & $\Delta \mathrm{IR}$ & 0.00003 & $\Delta \mathrm{IR}$ & 1.999 \\
\hline & NA\# & & NA\# & & NA\# & & NA\# & & NA\# \\
\hline $\mathrm{R}^{2}$ & 0.4 & $\mathrm{R}^{2}$ & 0.177 & $R^{2}$ & 0.16 & $\mathrm{R}^{2}$ & 0.155 & $\mathrm{R}^{2}$ & 0.195 \\
\hline Adjusted $\mathrm{R}^{2}$ & 0.12 & Adjusted $\mathrm{R}^{2}$ & -0.202 & Adjusted $\mathrm{R}^{2}$ & -0.22 & Adjusted $\mathrm{R}^{2}$ & $0.22^{*}$ & Adjusted $\mathrm{R}^{2}$ & -0.164 \\
\hline Standard Error & 0.006 & Standard Error & 0.008 & Standard Error & 0.008 & Standard Error & 0.008 & Standard Error & 17.55 \\
\hline Observations & 20 & Observations & 20 & Observations & 20 & Observations & 20 & Observations & 20 \\
\hline$F$ & 1.45 & $\mathrm{~F}$ & 0.467 & $\mathrm{~F}$ & 0.42 & $\mathrm{~F}$ & 0.153 & $\mathrm{~F}$ & 0.678 \\
\hline VIF Range & $1.196-1.549$ & VIF Range & $1.102-2.102$ & VIF Range & $1.102-2.102$ & VIF Range & $1.034-1.245$ & VIF Range & $1.034-1.245$ \\
\hline
\end{tabular}

Table 6: Linear regression test between brand equity and corporate governance sub-indices for 2016 and 2015. 


\begin{tabular}{|c|c|c|c|c|c|}
\hline ANOVA & df & SS & MS & F & Significance F \\
\hline Regression & 1 & 0.00032 & 0.00032 & 8.92 & 0.008 \\
\hline Residual & 18 & 0.00064 & 0.00003 & & \\
\hline Total & 19 & 0.00097 & & & \\
\hline
\end{tabular}

Table 7: ANOVA statistics.

the Corporate governance disclosures score of $2015, \mathrm{R}^{2}$ of 0.094 and adjusted $\mathrm{R}^{2}$ value of 0.044 were obtained. The standard error was 0.007 at a significance level of 95 per cent. The corresponding p-value for the intercept and coefficient of CGDS was 0.068 and 0.189 respectively. Since the p-value is $>0.05$, the hypothesis $H_{0 c}$ cannot be rejected. It can hence be concluded with 95 per cent certainty, that relationship between Brand Equity for 2016 and Corporate Governance Score of 2015 is not significant.

Testing Hypothesis: $\mathbf{H}_{0 \mathrm{~d}}$ : There is no relationship between Brand Equity of top 20 brands of India and functioning of board committees (represented by SBC) and Investor relations of these brands.

To test the above hypothesis linear regression at 95 per cent significance level was carried out between Brand Equity of year 2016 and year 2015 with the 6 Corporate Governance category/sub-indices for the corresponding year.

For the year 2016, the Strength of Board Committee had a coefficient of -0.002 at a p-value of 0.158 and Investor relation has a coefficient of -0.002 at a p-value lower than 0.05 . The $\mathrm{R}^{2}$ was 0.40 with standard error of 0.006 . All other sub-indices (BSI, RPD, BMR) showed similar coefficient but had $p$-value $>0.05$, indicating that these may not be right predictor for the model that was used. Board Meeting Rigor was expected to show a relationship with Brand Equity, as previous studies have found attendance at board meeting related to better performance $[16,23,61,62$,$] . This was however not witnessed in this study.$

The results with respect to SBC and IR showed no significant relationship between SBC and Brand Equity. IR had the highest coefficient among the sub-indices and showed relationship with Brand equity. 40 per cent variation in Brand Equity was explained by IR (p-value was $<0.05$ ).

For year 2015 as well, none of the sub-indices had coefficients with $\mathrm{p}$ value $<0.05$. The $\mathrm{R}^{2}$ value for 2015 was 0.177 at Standard error of 0.008 . For the year 2015, IR had a small coefficient $(-0.0004)$ at a p-value less than 0.05 . Based on the coefficient of other sub-indices and the corresponding p-values, it can be concluded that IR explained 17 per cent variation in Brand Equity.

In term of Hypothesis, since SBC showed insignificant relationship with Brand Equity, the Hypothesis $H_{o d}$ cannot be rejected. The regression model did not depict a relationship between Brand Equity with Strength of Board Committees and Investor Relation together. However, a relationship with Investor Relation on a standalone basis was noticed.

While studies show positive correlation between governance parameters like remuneration, board meetings, etc., an equivalent result was not evident in this case [17]. No relationship was found between Brand Equity and remuneration, although previous studies suggested its significance for the shareholders $[19,64,65]$.

\section{Other results}

From a model perspective, the regression between the Brand Equity value and differential sub-indices value (between 2016 and 2015) was also carried out. The results were however similar, with
Brand Equity showing a relationship with Investor Relation (IR). The differential Brand Equity created between 2016 and 2016 also showed a relationship between the Differential Investor Relation score. In both these cases the p-value was $<0.05$ for IR coefficients. Notably, board Structure which have been evidenced to impact Korean Firms [12] in terms of market value, does not seem to impact the Brand Equity values of Top 20 Indian Brands.

\section{Robustness of the Study}

Robustness of the study was carried through multicollinearity test and method validation.

\section{Multicollinearity}

In the multicollinearity test the VIF (Variance Inflation Factors) ranged from 1.034 to 2.102 across all regressions. These VIF values are much below the commonly accepted maximum of 10 [66-68]. This indicates very moderate correlation among the predictors and the regression coefficients are estimated well.

\section{Method validation}

Linear regression was selected after confirming that the relationship between Brand Equity and Corporate Governance Disclosure scores was linear. This was carried out using Passing and Bablok regression at 95 per cent confidence level.

\section{Conclusion}

This study examined the association and relationship between Brand Equity and Corporate Governance disclosures for Top 20 Indian Brands. Brand Equity figures from Interbrand was used for the year 2016 and 2015 was the dependent variable. An overall Corporate Governance Disclosure score and six sub-indices across Ownership Structure, Board Structure and Independence, Board Meeting Rigor, Strength of Board Committees, Remuneration Policy and Disclosure and Investor Relations was prepared using 67 questions. These were the independent variables.

Association of Corporate Governance Disclosure Score with Brand Equity was tested using Spearman Correlation Coefficient. Corporate Governance Disclosure Score were found to be significantly correlated with Brand Equity figures for year 2016. None of the six corporate governance sub-indices except Strength of Board Committees showed significant correlation with Brand Equity of 2016.

Regression between Brand Equity and Corporate Governance Disclosure Score of 2016 revealed significant relationship, with 33 per cent variation in Brand Equity explained by Corporate Governance Disclosure Score. Regression test between Brand Equity data of 2016 did not show a significant relationship with Corporate Governance Disclosures variable of 2015.

Regression test between Brand Equity of 2016 and the corporate governance sub-indices demonstrated significant relationship with one index of Investor Relations. 40 per cent variation in Brand Equity was explained by Investor Relations. For 2015, the results were similar with only Investor Relations showing a significant but weak relationship with Brand Equity. The results were similar when regression test between Brand Equity 2016 and the six sub-indices from 2015 as lagged variable was carried out.

There are key managerial implications arising from this study for brand management and corporate governance. Strong board committees, audit rigor, transparent remuneration and nomination 
policies creates a sense of integrity. These would propagate a strong organisation behavior which when coupled with brand development and management may lead to development of superior brands [69]. Ioannou and Serafeim [18] suggest that sustainability reporting not only increases transparency but can also change corporate behavior and there is a positive impact of this on responsible management practices.

Corporate governance lead social visibility and brand reputation impacts brand relationships [70]. Corporate governance disclosures and investor relations are key communication channels for creating the corporate identity, image and reputation [32,71,72]. Reputation and credibility are key to brand signaling and brand equity formation [73]. Positive reputation with successful corporate governance is can act as signal of quality and value and influence buyers to gravitate to products of a particular brand [74].

The study reveals that not all aspect of corporate governance impacts Brand Equity. Strong brand management with effective corporate governance can be one of the means to achieve enhanced Brand Equity. Corporate governance may not create brand equity by itself.

\section{Limitations}

This research is based on secondary data and the variables used by Interbrand to calculate Brand equity could not be tested. For a holistic view, Brand Equity variables and Corporate Governance variables need to be tested together. The Corporate Governance Disclosure Score did not consider the accuracy and quality aspect of the disclosures which are key parameters. As Firms may alter their governance structures in response to economic factors [75].

Small sample size of 20 was used. A bigger sample needs to be used to avoid impact on estimate of the strength of the relationship between the response and predictors. Although data for 2 years was used, a panel data across a larger sample will further add to the quality and outcome of such study. The study did not provide clarity if better corporate governance can lead to increased Brand Equity. A Sensitivity analysis is suggested to test this further. Independent calculation of Brand Equity and then testing its relationship with corporate governance variable is suggested to increase the reliability of this study. Despite this limitation, the study provides a view in the Indian context and add another dimension to the importance of Corporate Governance.

\section{Notes}

In the conclusion section the works of O'Cass and Ngo [69], Ioannou and Serafeim [18] Veloutsou and Moutinho [70], Balmer and Gray [72], Halliburton and Bach [32] Erdem and Swait [73] and Herbig and Milewicz [74] have been interpreted in the context of the study. No direct inferences are available in these studies for the conclusion drawn in this paper.

\section{References}

1. Kazmi A, Kazmi A (2015) Strategic management for sustainability, Strategic Management, 4th Edition, McGraw Hill Education (India) Private Limited, p: 73.

2. Cadbury Committee (1992) Report of the committee on the financial aspects of corporate.

3. Cherunilam F (2015) Corporate governance, Business Environment: text and cases. Mumbai: Himalayan Publishing House, pp: 207-221.

4. Krishnan KP, Nair CKG, Mitra A (2010) Anatomy and Limitations of a LegalCentric Approach to Corporate Governance. Corporate Governance and Emerging Scenario, NSE Publication, pp: 119-133.

5. Khanna V (2010) Enforcement of Corporate Governance in India: Steps
Forward, Corporate governance an emerging scenario. NSE Publication, pp: 134-165.

6. Javed AY, Iqbal R (2007) Relationship between Corporate Governance Indicators and Firm Value: A Case Study of Karachi Stock Exchange.

7. Banerjee A, Gokarn S, Pattanayak M, Sinha SK (2010) Corporate Governance and Market Value: Preliminary Evidence from Indian Companies. Corporate governance an emerging scenario. NSE Publication, pp: 166-178.

8. Farquhar PH (1989) Managing brand equity. Marketing Research 1: 24-33.

9. Wood L (2000) Brands and brand equity: Definition and management. Management Decision 38: 662-669.

10. Smith KT, Smith L M, Kun W (2010) Does Brand Management of Corporate Reputation Translate into Higher Market Value? Journal of Strategic Marketing

11. Skapinker M (2004) Brand strength proves its worth: Respect must be earned, then kept, says michaelskapinker. Financial Times.

12. Black BS, Jang H, Kim W (2012) Does Corporate Governance Predict Firms' Market Values? Evidence from Korea. Journal of Law, Economics \& Organization 22: 366-413.

13. Subramaniana S, Nagi RV (2011) Corporate governance disclosures and international competitiveness: A study of Indian Firms. Asian Business \& Management 11: 95-218.

14. Black B (2001) The corporate governance behavior and market value of Russian firms. Emerging Markets Review 2: 89-108.

15. Goel P, Ramesh RS (2016) Impact of Corporate Governance Practices on Firm Profitability: A study of Selected Industries in India. Journal of Finance, Accounting and Management 7: 53-74.

16. Arora A, Sharma C (2016) Corporate governance and firm performance in developing countries: Evidence from India. Corporate Governance 16: 420-436.

17. Brown LD, Caylor ML (2006) Corporate governance and firm valuation. Journal of Accounting and Public Policy 25: 409-434.

18. Ioannou I, Serafeim G (2014) The Consequences of Mandatory Corporate Sustainability Reporting. SEA - Practical Application of Science.

19. Bauer R, Frijns B, Otten R, Tourani (2008) The impact of corporate governance on corporate performance: Evidence from Japan. Pacific-Basin Finance Journal 16: 236-251.

20. Klapper LF, Love I (2002) Corporate Governance, Investor Protection and Performance in Emerging Markets. World Bank Policy Research Working Paper No: 2818.

21. Ettredge M, Johnstone K, Stone M (2011) The effects of firm size, corporate governance quality, and bad news on disclosure compliance. Review of Accounting Studies 16: 866-889.

22. Core JE, Robert WH, David FL (1999) Corporate governance, chief executive officer compensation, and firm performance. Journal of Financial Economics 51: $371-406$.

23. Bhatt RR, Bhattacharya S (2015) Board structure and firm performance in Indian IT firms. Journal of Advances in Management Research 12: 232-248.

24. Erkens DH, Hung M, Matos $P$ (2012) Corporate Governance in the 2007-2008 Financial Crisis: Evidence from Financial Institutions Worldwide. Journal of Corporate Finance 18: 389-411.

25. Kumar N, Singh JP (2013) Effect of board size and promoter ownership on firm value: Some empirical findings from India. Corporate Governance: The International Journal of Business in Society 13: 88-98.

26. Srivastava NK (2015) Does governance structure have any effect on firm performance during the financial crisis: Evidence from selected Indian companies. Journal of Strategy and Management 8: 368-383.

27. Ashbaugh-Skaife H, Collins DW, LaFond R (2006) The effects of corporate governance on firms' credit ratings. Journal of Accounting and Economics 42 : 203-243.

28. Dowling G (2006) How good corporate reputations create corporate value Corporate Reputation Review 9: 134-143.

29. Herciu M, Serban RA (2016) Creating value - from corporate governance to total shareholders return an overview. Studies in Business and Economics. 
Citation: Mishra P (2018) Relationship between Brand Equity and Corporate Governance Disclosures: A Study of Top 20 Brands in India. Bus Eco J 9: 355. doi: 10.4172/2151-6219.1000355

Page 9 of 9

30. Madden TJ, Fehle F, Fournier S (2006) Brands, Matter: An Empirical Demonstration of the Creation of Shareholder Value Through Branding. Journal of the Academy of Marketing Science 34: 224

31. Cobb-Walgren CJ, Ruble CA, Donthu N (1995) BrandEquity, Brand Preference, and Purchase Intent. Journal of Advertising 24: 25-40.

32. Halliburton C, Bach S (2012) An integrative framework of corporate brand equity. EuroMed Journal of Business 7: 243-255.

33. Lhotáková M (2013) The Growing Brand Equity and Brand Value - The Learnings from Most Valuable Brands. StudiacommercialiaBratislavensia 5 : 434-448.

34. Singh M, Kumar S (2016) Corporate Governance and Firm's Performance during Subprime Crisis: Evidence from Indian firms. Advances in Management

35. Zaharia C, Zaharia I (2012) Corporate governance and the market value of firms. Economics, Management \& Financial Markets 7: 227-232.

36. Kumar P, Kumar N, Gupta SK, Sharma RK (2017) Impact of Corporate Governance and Financial Parameters on Profitability of the BSE 100 Companies. IUP Journal of Corporate Governance 16: 7-26.

37. Lai C, Chiu C, Yang C, Pai D (2010) The effects of corporate social responsibility on brand performance: The mediating effect of industrial brand equity and corporate reputation. Journal of Business Ethics 95: 457-469.

38. Aggarwal R, Ghosh A (2015) Director's remuneration and correlation on firm's performance: A study from the Indian corporate. International Journal of Law and Management 57: 373-399.

39. Ploscaru C, Munteanu C, Florea D (2014) The implementation of corporate governance into brand management. SEA-Practical Application of Science.

40. Davies A (2006) Best Practice in Corporate Governance: Building Reputation and Sustainable Success. Gower Publishing Ltd, CRC Press, Business \& Economics.

41. Stuebs M, Sun L (2015) Corporate governance and social responsibility. International Journal of Law and Management 57: 38-52.

42. Shu-Hsun H, Jyh-Jeng W, Chen $Y$ (2010) Influence of Corporate Governance and Market Orientation on New Product Preannouncement: Evidence from Taiwan's Electronics Industry. Asia Pacific Management Review 15: 1-14.

43. Srinivasan V, Park CS, Chang DR (2005) An Approach to the Measurement Analysis, and Prediction of Brand Equity and Its Sources. Management Science 51: 1433-1448.

44. Bhojraj S, Sengupta P (2003) Effect of Corporate Governance on Bond Ratings and Yields: The Role of Institutional Investors and Outside Directors. The Journal of Business 76: 455-475.

45. Lennartz EM, Fischer M, Krafft M, Peters K (2015) Drivers of b2b brand strength - insights from an international study across industries. Schmalenbach Business Review: ZFBF 67: 114-137.

46. Aktaş R, Doğanay MM, Ali A,Ozan K (2015) The analysis of impact of the rating scores of firms in borsa Istanbul corporate governance index on brand value. International Research Journal of Marketing and Economics.

47. Ünlü U, Yagli I (2016) Corporate Governance and Brand Value. European Journal of Business and Management.

48. Tuan LT (2014).Corporate governance and brand performance. Management Research Review 37: 45-68.

49. Craig D, Karolyi GA, Stulz RM (2007) Why do countries matter so much for corporate governance? Journal of Financial Economics 86: 1-39.

50. Bauer R, Guenster N, Otten R (2004) Empirical Evidence on Corporate Governance in Europe: The Effect on Stock Returns, Firm Value and Performance. Journal of Asset Management 5: 91-104.

51. Madhani PM (2014) Corporate Governance and Disclosure Public Sector vs Private Sector. SCMS Journal of Indian Management 11: 5-20.

52. Madhani PM (2014) Corporate Governance and Disclosure Practices of Indian
Firms: An Industry Perspective. The IUP Journal of Corporate Governance 13 27-41

53. Madhani PM (2015) A Study on the Corporate Governance and Disclosure Practices of Tangible Assets- and Intangible Assets-Dominated Firms and Their Relationship. IUP Journal of Corporate Governance 14: 7-29.

54. Madhani PM (2016) Ownership Concentration, Corporate Governance and Disclosure Practices: A Study of Firms Listed in Bombay Stock Exchange. The IUP Journal of Corporate Governance 15: 7-36.

55. Duguleană L, DuguleanăC (2014) Brand valuation methodologies and practices. Bulletin of the Transilvania University of Braşov Series V: Economic Sciences.

56. Chu S, Keh HT (2006) Brand value creation: Analysis of the interbrandbusiness week brand value rankings. Marketing Letters 17: 323-331.

57. Sharma JP, Khanna S (2014) Corporate Social Responsibility, Corporate Governance and Sustainability: Synergies and Inter-relationships. Indian Journal of Corporate Governance.

58. Sarkar J, Sarkar S, Sen K (2012) A Corporate Governance Index for Large Listed Companies in India,pp: 1-35.

59. Aggarwal P (2013) Impact of Corporate Governance on Corporate Financial Performance. IOSR Journal of Business and Management 13: 1-5.

60. Varshney P, Kaul VK, Vasal VK (2012) Corporate Governance Index and Firm Performance: Empirical Evidence from India. SSRN Electronic Journal, pp: $1-35$.

61. Lipton M,Lorsch J (1992) A modest proposal for improved corporate governance. The Business Lawyer 48: 59-77.

62. Zahra SA, Pearce JA (1989) Boards of directors and corporate financial performance: a review and integrative model. Journal of Management 15: 291 334

63. Kyereboah-Coleman A (2007) Corporate governance and firm performance in Africa: a dynamic panel data analysis. Journal for Studies in Economics \& Econometrics 32: 1-24

64. Morck R, Nakamura M, Shivdasani A (2000) Banks, Ownership Structure, and Firm Value in Japan. The Journal of Business 73: 539-567.

65. Kato T, Kubo K (2006) CEO compensation and firm performance in Japan evidence from new panel data on individual CEO pay. Journal of the Japanese and International Economies 20: 1-19.

66. Hair JFJr, Anderson RE, Tatham RL, Black WC (1995) Multivariate Data Analysis (3rd edn). New York: Macmillan.

67. O'Brien RM (2007) A Caution Regarding Rules of Thumb for Variance Inflation Factors. Quality and Quantity 41: 673-690.

68. Neter J, Wasserman W, Kutner MH (1989) Applied Linear Regression Models.

69. O'Cass A, Ngo LV (2007) Market orientation versus innovative culture: two routes to superior brand performance. European Journal of Marketing 41 : 868-887.

70. Veloutsou C, Moutinho L (2009) Brand relationships through brand reputation and brand tribalism. Journal of Business Research 62: 314-322.

71. Aaker DA (1996) Measuring Brand Equity Across Products and Markets. California management review 38:102.

72. Balmer JMT, Gray ER (2000) Corporate identity and corporate communications: creating a competitive advantage. Industrial and Commercial Training 32: 256 262.

73. Erdem T, Swait J (1998) Brand Equity as a Signaling Phenomenon. Journal of Consumer Psychology 7: 131-157.

74. Herbig P, Milewicz J (1993) The relationship of reputation and credibility to brand success. Journal of Consumer Marketing 10: 18-24.

75. Gillan SL (2006) Recent Developments in Corporate Governance: An Overview. Journal of Corporate Finance 12: 381-402. 